\title{
Two Vanadium(V) Complexes Derived from Bromo and Chloro-Substituted Hydrazone Ligands: Syntheses, Crystal Structures and Antimicrobial Property
}

\author{
Zi-Qiang Sun, ${ }^{1}$ Shun-Feng Yu, ${ }^{1}$ Xin-Lan Xu, ${ }^{1}$ Xiao-Yang Qiu ${ }^{1,2, *}$ \\ and Shu-Juan Liu ${ }^{1}{ }^{*}$ \\ ${ }^{1}$ College of Science \& Technology, Ningbo University, Ningbo 315315, P.R. China \\ ${ }^{2}$ State Key Laboratory of Structural Chemistry, Fujian Institute of Research on the Structure of Matter, \\ Chinese Academy of Sciences, Fuzhou, Fujian 350002, P.R. China \\ *Corresponding author: E-mail: lsj_578@163.com
}

Received: 07-02-2020

\begin{abstract}
Two vanadium $(\mathrm{V})$ complexes derived from the bromo and chloro-substituted hydrazones $N$ '-(4-bromo-2-hydroxybenzylidene)-2-chlorobenzohydrazide $\left(\mathrm{H}_{2} \mathrm{~L}^{1}\right)$ and $\mathrm{N}^{\prime}$-(3-bromo-5-chloro-2-hydroxybenzylidene)-3-methylbenzohydrazide $\left(\mathrm{H}_{2} \mathrm{~L}^{2}\right)$ with the formula $\left[\mathrm{VOL}^{1}\left(\mathrm{OCH}_{3}\right)\left(\mathrm{CH}_{3} \mathrm{OH}\right)\right](\mathbf{1})$ and $\left[\mathrm{VOL}^{2}\left(\mathrm{OCH}_{3}\right)\left(\mathrm{CH}_{3} \mathrm{OH}\right)\right]$ (2) were newly synthesized and characterized by IR, UV-Vis and ${ }^{1} \mathrm{H}$ NMR spectroscopy. The structures of $\mathrm{H}_{2} \mathrm{~L}^{1}$ and the complexes were further confirmed by single crystal $\mathrm{X}$-ray diffraction. Both vanadium complexes are mononuclear, with the metal atoms coordinated by the hydrazone ligands, methanol ligands, and methanolate ligands, and the oxo groups, forming octahedral geometry. The hydrazones and the vanadium complexes were assayed for the antimicrobial activities on Bacillus subtilis, Staphylococcus aureus, Escherichia coli, and Pseudomonas fluorescence, and the fungi Candida albicans and Aspergillus niger. The existence of the bromo and chloro groups in the hydrazone ligands may improve the antimicrobial property.
\end{abstract}

Keywords: Hydrazone; vanadium; crystal structure; antimicrobial property

\section{Introduction}

Hydrazone compounds and their metal complexes have received particular attention due to their interesting biological aspects like antibacterial, ${ }^{1}$ antifungal, ${ }^{2}$ and antitumor. ${ }^{3}$ It has been proved that the compounds with electron-withdrawing substituent groups can enhance their antimicrobial ability. ${ }^{4}$ Rai et al. reported some compounds with fluoro, chloro, bromo, and iodo-substituted groups, and their remarkable antimicrobial property. ${ }^{5}$
Schiff base complexes of vanadium have potential antibacterial property. ${ }^{6}$ Recently, our research group has reported some hydrazone vanadium complexes with bromo or chloro-substituent groups. ${ }^{7}$ In pursuit of novel vanadium complex based antimicrobial agents, in this work, the bromo and chloro-substituent groups are incorporated together in the hydrazone compounds $N^{\prime}$-(4-bromo-2-hydroxybenzylidene)-2-chlorobenzohydrazide $\left(\mathrm{H}_{2} \mathrm{~L}^{1}\right)$ and $\mathrm{N}$ '-(3-bromo-5-chloro-2-hydroxybenzylidene)-3-meth-<smiles>O=C(N/N=C/c1ccc(Br)cc1O)c1ccccc1Cl</smiles>

$\mathrm{H}_{2} \mathrm{~L}^{1}$<smiles>Cc1cccc(C(=O)N/N=C/c2cc(Cl)cc(Br)c2O)c1</smiles>

$\mathrm{H}_{2} \mathrm{~L}^{2}$ 
ylbenzohydrazide $\left(\mathrm{H}_{2} \mathrm{~L}^{2}\right)$, and then coordinate with vanadium, to form two new new vanadium $(\mathrm{V})$ complexes, $\left[\mathrm{VOL}^{1}\left(\mathrm{OCH}_{3}\right)\left(\mathrm{CH}_{3} \mathrm{OH}\right)\right](\mathbf{1})$ and $\left[\mathrm{VOL}^{2}\left(\mathrm{OCH}_{3}\right)\left(\mathrm{CH}_{3} \mathrm{OH}\right)\right]$ (2). The antimicrobial properties of the compounds are presented.

\section{Experimental}

\section{1. Materials and Methods}

4-Bromosalicylaldehyde, 3-bromo-5-chlorosalicylaldehyde, 2-chlorobenzohydrazide, 3-methylbenzohydrazide and $\mathrm{VO}(\mathrm{acac})_{2}$ with $\mathrm{AR}$ grade were obtained from Sigma-Aldrich. All other chemicals were commercial obtained from Xiya Chemical Co. Ltd. Elemental analyses of $\mathrm{C}, \mathrm{H}$ and $\mathrm{N}$ were carried out in a Perkin-Elmer automated model 2400 Series II CHNS/O analyzer. The molar conductivity was determined using DDS-11A conductor device. FT-IR spectra were obtained on a Perkin-Elmer 377 FT-IR spectrometer with samples prepared as $\mathrm{KBr}$ pellets. UV-Vis spectra were obtained on a Lambda 35 spectrometer. ${ }^{1} \mathrm{H}$ NMR data were recorded on a Bruker $500 \mathrm{MHz}$ spectrometer. X-ray diffraction was carried out on a Bruker APEX II CCD diffractometer. Thermal analyses were carried out in Schimatzu DT6-60H thermogravimetric analyzer.

\section{2. Synthesis osf $\mathrm{H}_{2} \mathrm{~L}^{1}$}

4-Bromosalicylaldehyde $(0.010 \mathrm{~mol}, 2.0 \mathrm{~g})$ and 2-chlorobenzohydrazide $(0.010 \mathrm{~mol}, 1.7 \mathrm{~g})$ were reacted in methanol $(50 \mathrm{~mL})$ at room temperature for $30 \mathrm{~min}$. The solvent was removed by distillation, and the residue was recrystallized from methanol to give colorless crystalline product. Yield $92 \%$. Anal. Calc. for $\mathrm{C}_{14} \mathrm{H}_{10} \mathrm{BrClN}_{2} \mathrm{O}_{2}$ : C, 47.55; H, 2.85; N, 7.92. Found: C, 47.37; H, 2.93; N, 7.81\%. IR data $\left(\mathrm{cm}^{-1}\right): 3433,3208,1643,1614$. UV-Vis data $\left(\mathrm{MeOH}, \lambda_{\max }, \mathrm{nm}\right): 223,287,312,320,405 .{ }^{1} \mathrm{H}$ NMR $(500$ $\mathrm{MHz}, d^{6}$-DMSO): $\delta 12.32$ (s, 1H, OH), $11.31(\mathrm{~s}, 1 \mathrm{H}, \mathrm{NH})$, $8.66(\mathrm{~s}, 1 \mathrm{H}, \mathrm{CH}=\mathrm{N}), 7.69(\mathrm{~d}, 1 \mathrm{H}, \operatorname{Ar} H), 7.61(\mathrm{t}, 1 \mathrm{H}, \operatorname{Ar} H)$, 7.53-7.40 (m, 3H, ArH), 7.17 (s, $1 \mathrm{H}, \operatorname{ArH}), 7.12(\mathrm{~d}, 1 \mathrm{H}$, $\operatorname{ArH}) .{ }^{13} \mathrm{C}$ NMR (126 MHz, $d^{6}$-DMSO): $\delta 164.18,161.27$, $145.22,136.73,134.12,132.59,132.26,129.81,128.33$, $127.10,123.35,122.08,116.34,114.91$.

Single crystals of the compound $\mathrm{H}_{2} \mathrm{~L}^{1}$ were obtained by slow evaporation of the methanolic solution in air for a week.

\section{3. Synthesis of $\mathbf{H}_{2} \mathrm{~L}^{2}$}

3-Bromo-5-chlorosalicylaldehyde $(0.010 \mathrm{~mol}, 2.3 \mathrm{~g})$ and 3-methylbenzohydrazide $(0.010 \mathrm{~mol}, 1.5 \mathrm{~g})$ were reacted in methanol $(50 \mathrm{~mL})$ at room temperature for 30 min. The solvent was removed by distillation, and the residue was recrystallized from methanol to give colorless crystalline product. Yield 95\%. Anal. Calc. for $\mathrm{C}_{15} \mathrm{H}_{12}$
$\mathrm{BrClN}_{2} \mathrm{O}_{2}$ : C, 49.01; H, 3.29; N, 7.62. Found: C, 48.83; H, 3.22; N, 7.45\%. IR data $\left(\mathrm{cm}^{-1}\right): 3430,3201,1645,1613$. UV-Vis data $\left(\mathrm{MeOH}, \lambda_{\max }, \mathrm{nm}\right): 225,290,310,323,402$. ${ }^{1} \mathrm{H}$ NMR (500 MHz, d6-DMSO): $\delta 12.51(\mathrm{~s}, 1 \mathrm{H}, \mathrm{OH})$, $11.27(\mathrm{~s}, 1 \mathrm{H}, \mathrm{NH}), 8.64(\mathrm{~s}, 1 \mathrm{H}, \mathrm{CH}=\mathrm{N}), 7.82(\mathrm{~d}, 1 \mathrm{H}, \operatorname{Ar} H)$, 7.71 (s, 1H, ArH), 7.55 (s, 1H, ArH), 7.51-7.46 (m, 2H, $\mathrm{ArH}), 7.35$ (t, $1 \mathrm{H}, \mathrm{ArH}), 2.38\left(\mathrm{~s}, 3 \mathrm{H}, \mathrm{CH}_{3}\right) .{ }^{13} \mathrm{C} \mathrm{NMR}(126$ $\mathrm{MHz}, d^{6}$-DMSO): $\delta 164.03,160.15,145.31,139.12,137.06$, $133.39,132.22,131.58,129.74,129.31,128.45,125.67$, $121.17,114.49,21.08$.

\section{4. Synthesis of Complex 1}

$\mathrm{H}_{2} \mathrm{~L}^{1}(0.10 \mathrm{mmol}, 35 \mathrm{mg})$ and $\mathrm{VO}(\mathrm{acac})_{2}(0.10 \mathrm{mmol}$, $26 \mathrm{mg})$ were reacted in methanol $(10 \mathrm{~mL})$ at reflux for $1 \mathrm{~h}$ and then cooled to room temperature. Block brown single crystals of the complex, suitable for X-ray diffraction, were grown from the solution upon slowly evaporation within a few days. The crystals were isolated by filtration. Yield $45 \%$. Anal. calc. for $\mathrm{C}_{16} \mathrm{H}_{15} \mathrm{BrClN}_{2} \mathrm{O}_{5} \mathrm{~V}: \mathrm{C}, 39.90 ; \mathrm{H}, 3.14$; N, 5.82; found: C, $39.72 ; \mathrm{H}, 3.26 ; \mathrm{N}, 5.95 \%$. IR data $\left(\mathrm{cm}^{-1}\right)$ : $3451(\mathrm{w}), 1607(\mathrm{~s}), 956(\mathrm{~m})$. UV-Vis data $\left(\mathrm{MeOH}, \lambda_{\max }\right.$, $\mathrm{nm}): 275,331 .{ }^{1} \mathrm{H}$ NMR $\left(500 \mathrm{MHz}, d^{6}\right.$-DMSO): $\delta 8.92(\mathrm{~s}$, $1 \mathrm{H}, \mathrm{CH}=\mathrm{N}), 7.82(\mathrm{~d}, 1 \mathrm{H}, \operatorname{Ar} H), 7.67(\mathrm{~d}, 1 \mathrm{H}, \operatorname{Ar} H), 7.58-$ 7.45 (m, 3H, ArH), 7.19 (s, 1H, ArH), 7.17 (d, 1H, ArH), $5.28\left(\mathrm{~s}, 3 \mathrm{H}, \mathrm{CH}_{3}\right), 3.17\left(\mathrm{~s}, 3 \mathrm{H}, \mathrm{CH}_{3}\right) .{ }^{13} \mathrm{C} \mathrm{NMR}(126 \mathrm{MHz}$, $d^{6}$-DMSO): $\delta 170.71,163.20,152.57,134.30,131.99$, $131.78,131.20,130.75,130.62,127.77,127.12,122.56$, $119.50,119.38,74.43,48.58 . \Lambda_{\mathrm{M}}\left(10^{-3} \mathrm{M}\right.$ in methanol): 37 $\Omega^{-1} \mathrm{~cm}^{2} \mathrm{~mol}^{-1}$.

\section{5. Synthesis of Complex 2}

$\mathrm{H}_{2} \mathrm{~L}^{2}(0.10 \mathrm{mmol}, 37 \mathrm{mg})$ and $\mathrm{VO}(\mathrm{acac})_{2}(0.10$ $\mathrm{mmol}, 26 \mathrm{mg})$ were reacted in methanol $(10 \mathrm{~mL})$ at reflux for $1 \mathrm{~h}$ and then cooled to room temperature. Block brown single crystals of the complex, suitable for X-ray diffraction, were grown from the solution upon slowly evaporation within a few days. The crystals were isolated by filtration. Yield $38 \%$. Anal. calc. for $\mathrm{C}_{17} \mathrm{H}_{17} \mathrm{BrClN}_{2} \mathrm{O}_{5} \mathrm{~V}$ : C, 41.20; $\mathrm{H}, 3.46 ; \mathrm{N}, 5.65$; found: $\mathrm{C}, 41.32 ; \mathrm{H}, 3.53 ; \mathrm{N}, 5.57 \%$. IR data $\left(\mathrm{cm}^{-1}\right): 3445(\mathrm{w}), 1605(\mathrm{~s}), 955(\mathrm{~m})$. UV-Vis data $\left(\mathrm{MeOH}, \lambda_{\max }, \mathrm{nm}\right): 273,327 .{ }^{1} \mathrm{H}$ NMR $(500 \mathrm{MHz}$, $d^{6}$-DMSO): $\delta 8.92(\mathrm{~s}, 1 \mathrm{H}, \mathrm{CH}=\mathrm{N}), 7.92(\mathrm{~d}, 1 \mathrm{H}, \mathrm{ArH})$, 7.85-7.83 (m, 3H, ArH), 7.40-7.27 (m, 2H, ArH), 5.39 (s, $\left.3 \mathrm{H}, \mathrm{CH}_{3}\right), 3.17\left(\mathrm{~s}, 3 \mathrm{H}, \mathrm{CH}_{3}\right), 2.39\left(\mathrm{~s}, 3 \mathrm{H}, \mathrm{CH}_{3}\right) .{ }^{13} \mathrm{C} \mathrm{NMR}$ (126 MHz, $d^{6}$-DMSO): $\delta 171.46,157.45,150.84,137.91$, $135.15,132.40,131.19,130.34,128.59,128.55,125.41$, $122.74,121.95,111.95,75.17,48.57,20.93 . \Lambda_{\mathrm{M}}\left(10^{-3} \mathrm{M}\right.$ in methanol): $33 \Omega^{-1} \mathrm{~cm}^{2} \mathrm{~mol}^{-1}$.

\section{6. X-ray Crystallography}

$\mathrm{X}$-ray diffraction was carried out at a Bruker APEX II CCD area diffractometer equipped with MoKa radiation $(\lambda=0.71073 \AA)$. The collected data were reduced with 
Table 1. Crystallographic and refinement data for the complexes

\begin{tabular}{|c|c|c|c|}
\hline Complex & $\mathbf{H}_{2} \mathrm{~L}^{1}$ & 1 & 2 \\
\hline Formula & $\mathrm{C}_{14} \mathrm{H}_{10} \mathrm{BrClN}_{2} \mathrm{O}_{2}$ & $\mathrm{C}_{16} \mathrm{H}_{15} \mathrm{BrClN}_{2} \mathrm{O}_{5} \mathrm{~V}$ & $\mathrm{C}_{17} \mathrm{H}_{17} \mathrm{BrClN}_{2} \mathrm{O}_{5} \mathrm{~V}$ \\
\hline Formula weight & 353.60 & 481.60 & 495.63 \\
\hline$T(\mathrm{~K})$ & $298(2)$ & $298(2)$ & $298(2)$ \\
\hline Crystal system & Monoclinic & Monoclinic & Monoclinic \\
\hline Space group & $P 2_{1} / n$ & $P 2_{1} / c$ & $P 2_{1} / c$ \\
\hline$a(\AA)$ & $7.3644(12)$ & $10.7402(12)$ & $13.1333(10)$ \\
\hline$b(\AA)$ & $26.8935(13)$ & $20.4546(15)$ & $18.6524(12)$ \\
\hline$c(\AA)$ & $7.6148(12)$ & $8.3295(7)$ & $7.9156(7)$ \\
\hline$\alpha\left({ }^{\circ}\right)$ & 90 & 90 & 90 \\
\hline$\beta\left({ }^{\circ}\right)$ & $112.277(1)$ & $94.601(1)$ & $89.986(1)$ \\
\hline$\gamma\left({ }^{\circ}\right)$ & 90 & 90 & 90 \\
\hline$V\left(\AA^{3}\right)$ & $1395.6(3)$ & $1824.0(3)$ & 1939.1(3) \\
\hline$Z$ & 4 & 4 & 4 \\
\hline$D_{\text {calc }}\left(\mathrm{g} \mathrm{cm}^{-3}\right)$ & 1.683 & 1.754 & 1.698 \\
\hline$\mu(\mathrm{Mo} \mathrm{Ka})\left(\mathrm{mm}^{-1}\right)$ & 3.138 & 2.911 & 2.741 \\
\hline$F(000)$ & 704 & 960 & 992 \\
\hline Measured reflections & 8162 & 10588 & 13404 \\
\hline Unique reflections & 2587 & 3378 & 2919 \\
\hline Observed reflections $\left(I^{3} 2 \sigma(I)\right)$ & 1275 & 1693 & 2030 \\
\hline Parameters & 187 & 238 & 250 \\
\hline Restraints & 2 & 1 & 3 \\
\hline GOF & 1.009 & 0.979 & 1.061 \\
\hline$R_{1}, w R_{2}[I \geq 2 \sigma(I)]^{a}$ & $0.0630,0.1356$ & $0.0655,0.1226$ & $0.0833,0.1941$ \\
\hline$R_{1}, w R_{2}(\text { all data })^{a}$ & $0.1523,0.1746$ & $0.1556,0.1542$ & $0.1232,0.2154$ \\
\hline
\end{tabular}

${ }^{\mathrm{a}} R_{1}=\Sigma|| F_{\mathrm{o}}|-| F_{\mathrm{c}}|| / \Sigma\left|F_{\mathrm{o}}\right|, w R_{2}=\left\{\Sigma\left[w\left(F_{\mathrm{o}}{ }^{2}-F_{\mathrm{c}}{ }^{2}\right)^{2}\right] / \Sigma\left[w\left(F_{\mathrm{o}}{ }^{2}\right)^{2}\right]\right\}^{1 / 2}$

Table 2. Selected bond distances $(\AA)$ and angles $\left({ }^{\circ}\right)$ for the complexes

\begin{tabular}{lrr}
\hline & $\mathbf{1}$ & \multicolumn{1}{c}{$\mathbf{2}$} \\
\hline $\mathrm{V} 1-\mathrm{O} 1$ & $1.851(5)$ & $1.887(5)$ \\
$\mathrm{V} 1-\mathrm{O} 2$ & $1.961(5)$ & $1.977(6)$ \\
$\mathrm{V} 1-\mathrm{O} 3$ & $2.308(5)$ & $2.329(6)$ \\
$\mathrm{V} 1-\mathrm{O} 4$ & $1.756(5)$ & $1.756(5)$ \\
$\mathrm{V} 1-\mathrm{O} 5$ & $1.573(5)$ & $1.582(7)$ \\
$\mathrm{V} 1-\mathrm{N} 1$ & $2.109(6)$ & $2.138(6)$ \\
$\mathrm{O} 5-\mathrm{V} 1-\mathrm{O} 4$ & $101.6(2)$ & $103.3(3)$ \\
$\mathrm{O} 5-\mathrm{V} 1-\mathrm{O} 1$ & $100.1(2)$ & $98.1(3)$ \\
$\mathrm{O} 4-\mathrm{V} 1-\mathrm{O} 1$ & $104.7(2)$ & $100.9(3)$ \\
$\mathrm{O} 5-\mathrm{V} 1-\mathrm{O} 2$ & $97.7(2)$ & $98.5(3)$ \\
$\mathrm{O} 4-\mathrm{V} 1-\mathrm{O} 2$ & $92.6(2)$ & $96.3(2)$ \\
$\mathrm{O} 1-\mathrm{V} 1-\mathrm{O} 2$ & $152.0(2)$ & $152.5(2)$ \\
$\mathrm{O} 5-\mathrm{V} 1-\mathrm{N} 1$ & $95.0(2)$ & $94.4(3)$ \\
$\mathrm{O} 4-\mathrm{V} 1-\mathrm{N} 1$ & $160.0(2)$ & $83.5(2)$ \\
$\mathrm{O} 1-\mathrm{V} 1-\mathrm{N} 1$ & $82.9(2)$ & $73.6(2)$ \\
$\mathrm{O} 2-\mathrm{V} 1-\mathrm{N} 1$ & $74.1(2)$ & $81.3(2)$ \\
$\mathrm{O} 5-\mathrm{V} 1-\mathrm{O} 3$ & $175.6(2)$ & $82.5(2)$ \\
$\mathrm{O} 4-\mathrm{V} 1-\mathrm{O} 3$ & $82.5(2)$ & $79.1(2)$ \\
$\mathrm{O} 1-\mathrm{V} 1-\mathrm{O} 3$ & $80.2(2)$ & $80.8(2)$ \\
$\mathrm{O} 2-\mathrm{V} 1-\mathrm{O} 3$ & $80.4(2)$ & \\
N1-V1-O3 & $80.6(2)$ & \\
\hline
\end{tabular}

SAINT, ${ }^{8}$ and multi-scan absorption correction was performed using SADABS. ${ }^{9}$ The structures of the complexes were solved by direct method, and refined against $F^{2}$ by full-matrix least-squares method using SHELXTL. ${ }^{10}$ All of the non-hydrogen atoms were refined anisotropically. The hydrogen atoms bond to $\mathrm{N}$ and $\mathrm{O}$ atoms were located from electronic density maps with $\mathrm{O}-\mathrm{H}$ and $\mathrm{N}-\mathrm{H}$ groups refined fixing the bond lengths. The $U_{\text {iso }}(\mathrm{H})$ were set to $1.5 U_{\text {eq }}(\mathrm{O})$ and $1.2 U_{\text {eq }}(\mathrm{N})$. The remaining hydrogen atoms were placed in calculated positions and constrained to ride on their parent atoms. The crystallographic data and refinement parameters for $\mathrm{H}_{2} \mathrm{~L}^{1}$ and the complexes are listed in Table 1. Selected bond lengths and angles are listed in Table 2.

\section{7. Antimicrobial Assay}

The antibacterial activities of the hydrazone compounds and the vanadium complexes were tested against B. subtilis, S. aureus, E. coli, and P. fluorescence using $\mathrm{MH}$ (Mueller-Hinton) medium. The antifungal activities of the compounds were tested against $C$. albicans and $A$. niger using RPMI-1640 medium. The MIC values of the tested compounds were determined by a colorimetric method using the dye MTT. ${ }^{11}$ A stock solution of the compound $\left(150 \mu \mathrm{g} \mathrm{mL}^{-1}\right)$ in DMSO was prepared and graded quantities $\left(75,37.5,18.8,9.4,4.7,2.3,1.2,0.59 \mu \mathrm{g} \mathrm{mL}^{-1}\right)$ were incorporated in specified quantity of the corresponding sterilized liquid medium. A specified quantity of the medium containing the compound was poured into micro-titration plates. Suspension of the microorganism was pre- 
pared to contain approximately $1.0 \times 10^{5} \mathrm{cfu} \mathrm{mL}^{-1}$ and applied to microtitration plates with serially diluted compounds in DMSO to be tested and incubated at $37^{\circ} \mathrm{C}$ for $24 \mathrm{~h}$ and $48 \mathrm{~h}$ for bacteria and fungi, respectively. Then the MIC values were visually determined on each of the microtitration plates, $50 \mu \mathrm{L}$ of PBS (phosphate buffered saline $0.01 \mathrm{~mol} \mathrm{~L}^{-1}, \mathrm{pH}=7.4$ ) containing $2 \mathrm{mg}$ of $\mathrm{MTT} \mathrm{mL}^{-1}$ was added to each well. Incubation was continued at room temperature for $4-5 \mathrm{~h}$. The content of each well was removed and $100 \mu \mathrm{L}$ of isopropanol containing $5 \% \mathrm{HCl}$ $\left(1 \mathrm{~mol} \mathrm{~L}^{-1}\right)$ was added to extract the dye. After $12 \mathrm{~h}$ of incubation at room temperature, the optical density was measured with a microplate reader at $550 \mathrm{~nm}$.

\section{Results and Discussion}

\section{1. Synthesis and Characterization}

The hydrazones $\mathrm{H}_{2} \mathrm{~L}^{1}$ and $\mathrm{H}_{2} \mathrm{~L}^{2}$ were readily prepared by the condensation reaction of a 1:1 molar ratio of 4-bromosalicylaldehyde with 2-chlorobenzohydrazide, and 3-bromo-5-chlorosalcylaldehyde with 3-methylbenzohydrazide, respectively in methanol. Single crystals of $\mathrm{H}_{2} \mathrm{~L}^{1}$ were obtained by slow evaporation of its methanolic solution. However, it is difficult to obtain the single crystals of $\mathrm{H}_{2} \mathrm{~L}^{2}$ even with the attempts of various solvents. The vanadium complexes were obtained by the reaction of the hydrazones with $\mathrm{VO}(\mathrm{acac})_{2}$ in methanol, followed by recrystallization. Elemental analyses of the hydrazones and the vanadium complexes are in accordance with the molecular structures determined by the single crystal X-ray analysis.

\section{2. Spectroscopic Studies}

In the spectra of the hydrazone compounds $\mathrm{H}_{2} \mathrm{~L}^{1}$ and $\mathrm{H}_{2} \mathrm{~L}^{2}$, and the vanadium complexes, the weak bands in the range $3400-3500 \mathrm{~cm}^{-1}$ are attributed to the vibration of the $\mathrm{O}-\mathrm{H}$ bonds. The sharp bands of the hydrazone compounds $\mathrm{H}_{2} \mathrm{~L}^{1}$ and $\mathrm{H}_{2} \mathrm{~L}^{2}$ observed at $3200-3210 \mathrm{~cm}^{-1}$ are assigned to the vibration of the $\mathrm{N}-\mathrm{H}$ bonds. The strong absorptions at $1643-1645 \mathrm{~cm}^{-1}$ of the hydrazone compounds are generated by the vibrations of the $\mathrm{C}=\mathrm{O}$ bonds, whereas the bands at $1613-1614 \mathrm{~cm}^{-1}$ by the $\mathrm{C}=\mathrm{N}$ bonds. The absence of the $v(\mathrm{C}=\mathrm{O})$ and $v(\mathrm{~N}-\mathrm{H})$ bands, which present in the spectra of the hydrazones, implies the enolization of the amide functionality upon coordination to the $\mathrm{V}$ atoms. The strong absorption bands at 1605-1607 $\mathrm{cm}^{-1}$ can be assigned to the stretching vibrations of the $\mathrm{C}=\mathrm{N}$ bonds. The typical bands at $955-956 \mathrm{~cm}^{-1}$ for the complexes could be clearly identified to the $v(\mathrm{~V}=\mathrm{O})$ for the complexes. ${ }^{12}$

In the UV-Vis spectra of the hydrazones and the vanadium complexes, the bands at $320-340 \mathrm{~nm}$ are assigned to the intra-ligand $\pi \rightarrow \pi^{*}$ absorptions. In the spectra of the vanadium complexes, the lowest energy transition bands observed at $400 \mathrm{~nm}$ are due to the LMCT transition as charge transfer from $p$-orbital on the lone-pair of ligands' oxygen atoms to the empty $d$-orbital of the vanadium atoms. The other mainly LMCT and to some extent $\pi \rightarrow \pi^{\star}$ bands appear at about $275 \mathrm{~nm}$ for the vanadium complexes are attributed to the oxygen donor atoms bound to $\mathrm{V}$ atoms. ${ }^{12}$

The ${ }^{1} \mathrm{H}$ NMR spectra of the hydrazones $\mathrm{H}_{2} \mathrm{~L}^{1}$ and $\mathrm{H}_{2} \mathrm{~L}^{2}$ exhibit $\mathrm{OH}$ (phenolic) resonances at 12.32 and 12.51 $\mathrm{ppm}$, respectively. Signals for one $\mathrm{CH}$ proton at $8.66 \mathrm{ppm}$, and one $\mathrm{NH}$ proton at $11.31 \mathrm{ppm}$ for $\mathrm{H}_{2} \mathrm{~L}^{1}$, and signals for one $\mathrm{CH}=\mathrm{N}$ proton at $8.64 \mathrm{ppm}$, and one $\mathrm{NH}$ proton at $11.27 \mathrm{ppm}$ for $\mathrm{H}_{2} \mathrm{~L}^{2}$. Signals for aromatic protons are found in the 7.69-7.12 ppm range. Signals for methyl protons of $\mathrm{H}_{2} \mathrm{~L}^{2}$ are found at $2.32 \mathrm{ppm}$.

\section{3. Structure Description of $\mathrm{H}_{2} \mathrm{~L}^{1}$}

Molecular structure of $\mathrm{H}_{2} \mathrm{~L}^{1}$ is shown in Figure 1 . The molecule adopts $E$ configuration about the methylidene group. The distance of the C7-N1 group, 1.266(8) $\AA$, indicates it a typical double bond. The distance of the C8-N2 bond (1.352(9) $\AA$ ) is shorter, and that of the $\mathrm{C} 8-\mathrm{O} 2$ bond $(1.222(7) \AA$ ) for the $-\mathrm{C}(\mathrm{O})-\mathrm{NH}-$ unit is longer than usual, implies the conjugation effects in the hydrazone molecule. The bond lengths and angles in this compound are within normal values. ${ }^{4 a}$ The two aromatic rings $\mathrm{C} 1-\mathrm{C} 6$ and $\mathrm{C} 9-\mathrm{C} 14$ form a dihedral angle of $20.5(5)^{\circ}$. In the crystal structure of the compound, the molecules

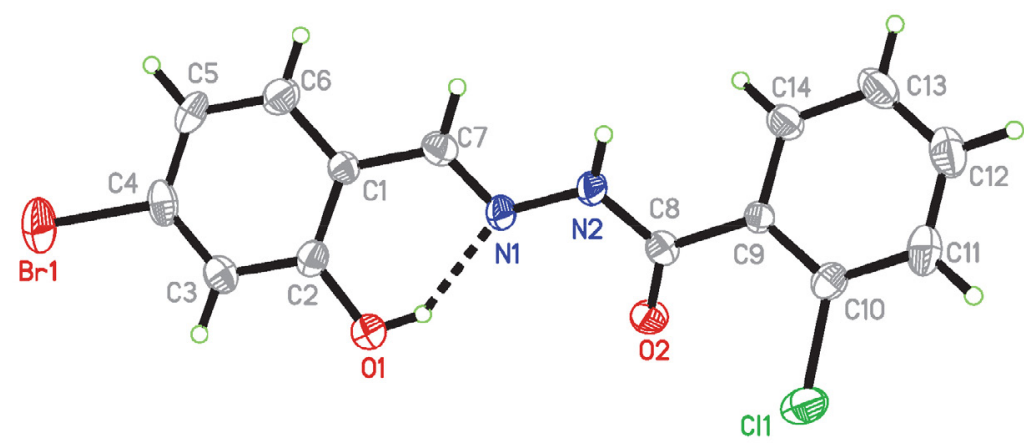

Figure 1. A perspective view of $\mathrm{H}_{2} \mathrm{~L}^{1}$ with the atom labeling scheme. Thermal ellipsoids are drawn at the $30 \%$ probability level. Hydrogen bond is shown as a dotted line. 


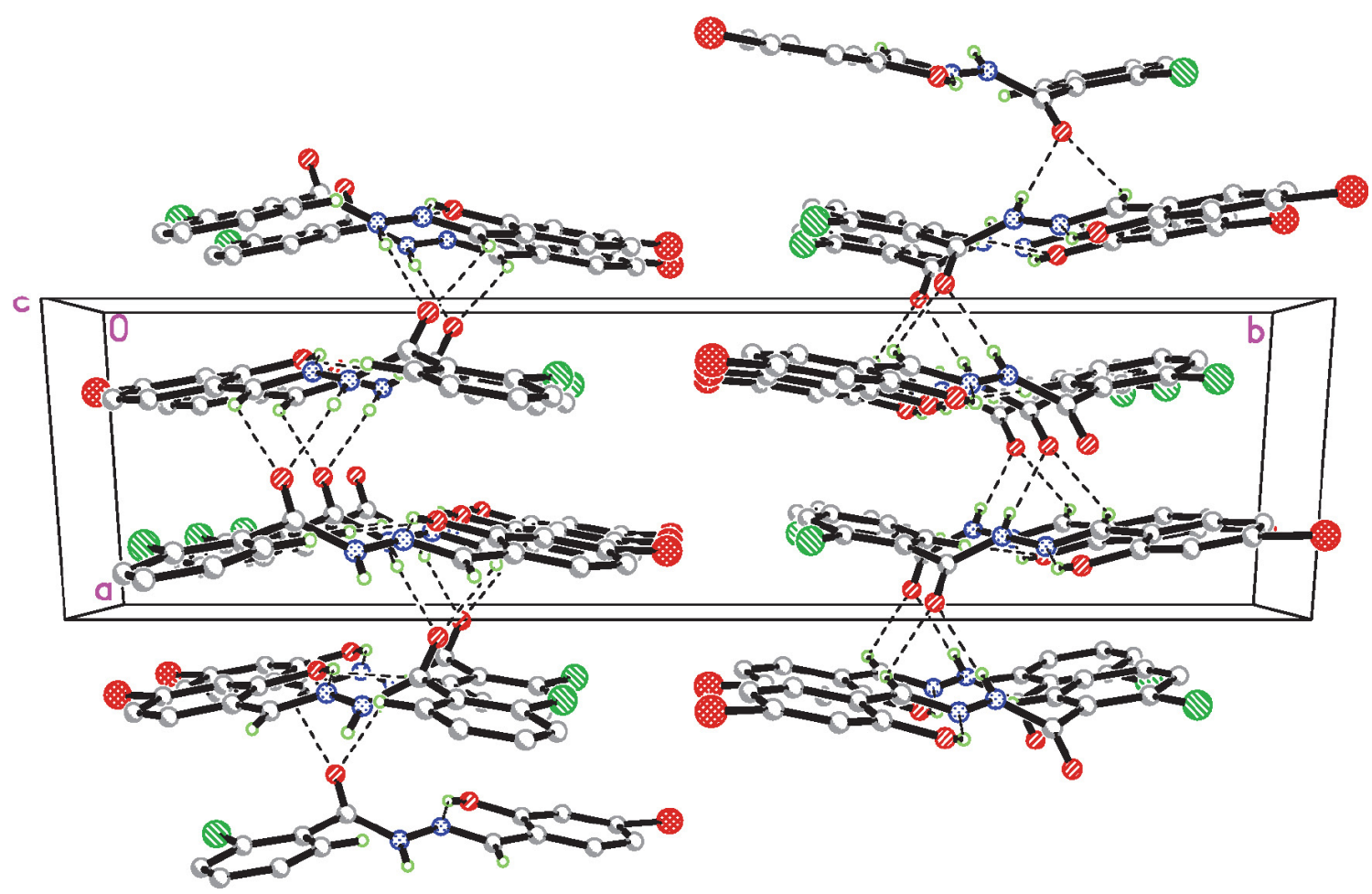

Figure 2. Molecular packing structure of $\mathrm{H}_{2} \mathrm{~L}^{1}$, with hydrogen bonds shown as dotted lines.

are linked through $\mathrm{N}-\mathrm{H} \cdots \mathrm{O}$ and non-classical C-H...O hydrogen bonds (Table 3 ), to form chains along the $a$-axis direction (Figure 2).

\section{4. Structure Description of the Complexes}

Molecular structures of the vanadium complexes 1 and 2 are shown in Figures 3 and 4, respectively. The coordination spheres around the $\mathrm{V}$ atoms are best described as distorted octahedral geometry. The hydrazones, act as tridentate ligands, chelate the $\mathrm{V}$ atoms in a meridional fashion, generating one five and one six-membered rings with bite angles of $73.6(2)-74.1(2)^{\circ}$ and $82.9(2)-83.5(2)^{\circ}$, respectively. This is not uncommon for this type of ligand systems. ${ }^{13}$ Each hydrazone ligand lies in a plane with one hydroxylato ligand which lies trans to the hydrazone imino nitrogen atom. The oxygen atoms of the methanol ligands trans to the oxo oxygen atoms complete the distorted octahedral coordination spheres at rather elongated distances of 2.306(5)-2.329(6) $\AA$, due to the trans effects of the oxo groups. This is accompanied by significant displacements of the $\mathrm{V}$ atoms of complexes $\mathbf{1}$ and $\mathbf{2}$ from the planes defined by the four basal donor atoms toward the apical oxo oxygen atoms by $0.295(3)$ and $0.299(3) \AA$, respectively. As

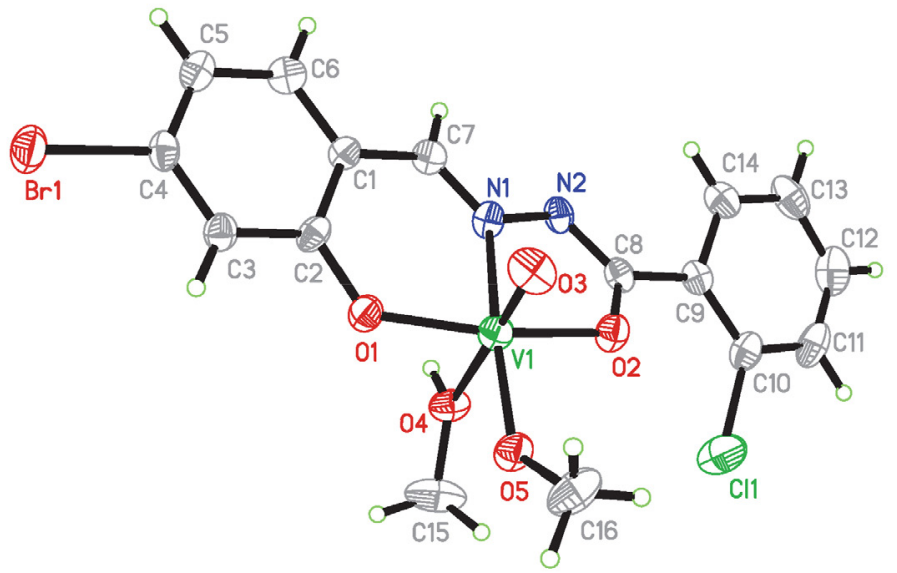

Figure 3. A perspective view of complex 1 with the atom labeling scheme. Thermal ellipsoids are drawn at the $30 \%$ probability level. 


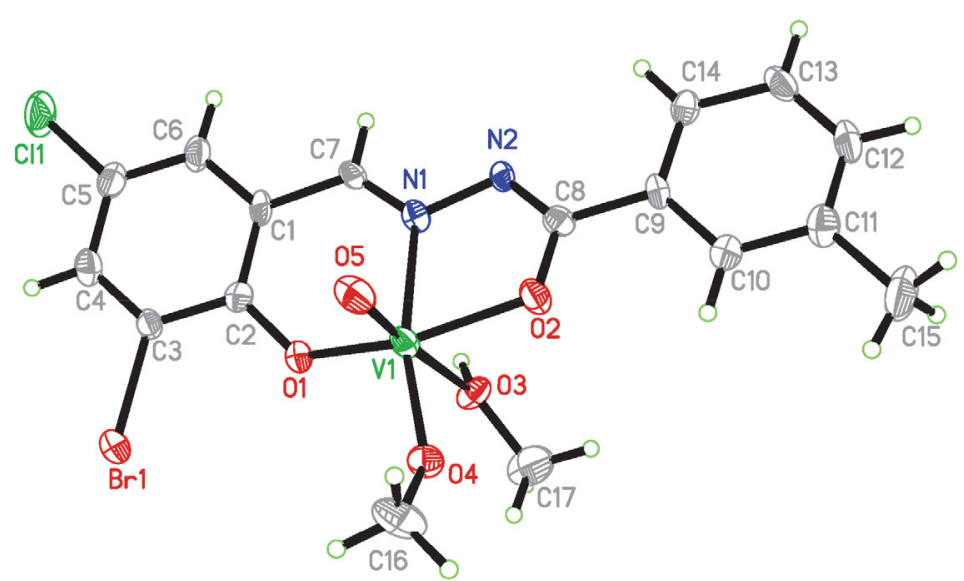

Figure 4. A perspective view of complex 2 with the atom labeling scheme. Thermal ellipsoids are drawn at the $30 \%$ probability level.

expected, the hydrazone ligands coordinate in their doubly deprotonated enolate form which is consistent with the observed $\mathrm{O} 2-\mathrm{C} 8$ and $\mathrm{N} 2-\mathrm{C} 8$ bond lengths of 1.28-1.31 and 1.29-1.31 A. This agrees well with reported vanadium complexes with the enolate form of this type of ligands. ${ }^{14}$

In the crystal packing structure of complex $\mathbf{1}$, the molecules are linked by hydrogen bonds (Table 3 ), leading to the formation of dimers (Figure 5). In the crystal packing structure of complex 2 , the molecules are linked by hydrogen bonds (Table 3), leading to the formation of chains along the $c$-axis direction (Figure 6).

\section{5. Antimicrobial Activity}

The hydrazone compounds and the vanadium complexes were screened for antibacterial activities against two Gram (+) bacterial strains (Bacillus subtilis and Staphylococcus aureus) and two Gram (-) bacterial strains (Escherichia coli and Pseudomonas fluorescence) by MTT method. The MIC (minimum inhibitory concentration, $\mu \mathrm{g} \mathrm{mL}{ }^{-1}$ ) values of the compounds against four bacteria are listed in
Table 4. Penicillin G was used as the standard drug. Both hydrazone compounds show medium activity against $B$. subtilis and $S$. aureus, weak activity against $E$. coli, and no activity against $P$. fluorescence. $\mathrm{H}_{2} \mathrm{~L}^{2}$ has stronger activities against the bacteria than $\mathrm{H}_{2} \mathrm{~L}^{1}$ except for $P$. fluorescence. The vanadium complexes, in general, have stronger activities against the bacteria than the free hydrazones. The complexes have strong activities against $B$. subtilis, $S$. aureus and E. coli which are comparable to Penicillin G. Complex $\mathbf{1}$ has no activity against $P$. fluoresence, while complex $\mathbf{2}$ has weak activity. Both complexes have no activity on the fungal strains Candida albicans and Aspergillus niger.

Interestingly, the bromo and chloro-containing hydrazone $\mathrm{H}_{2} \mathrm{~L}^{2}$ is more active than the bromo and methoxy-containing hydrazones $N^{\prime}$-(3-bromo-2-hydroxybenzylidene)-3-hydroxy-4-methoxybenzohydrazide and N'- (3-bromo-2-hydroxybenzylidene)-3,5-dimethoxybenzohydrazide. $^{\text {7a }}$ Subsequently, the complex 2 with bromo and chloro-containing hydrazone ligand is more active than the vanadium complex with bromo and methoxy-containing hydrazone ligand on S. aureus and P. fluorescence. ${ }^{\text {a }}$

Table 3. Hydrogen bond distances $(\AA)$ and bond angles $\left(^{\circ}\right)$ for the compounds

\begin{tabular}{llllc}
\hline $\boldsymbol{D}-\mathrm{H} \cdots \boldsymbol{A}$ & $\boldsymbol{d}(\boldsymbol{D}-\mathbf{H})$ & $\boldsymbol{d}(\mathbf{H} \cdots \boldsymbol{A})$ & $\boldsymbol{d}(\boldsymbol{D} \cdots \boldsymbol{A})$ & Angle $(\boldsymbol{D}-\mathbf{H} \cdots \boldsymbol{A})$ \\
\hline $\mathrm{H}_{2} \mathrm{~L}^{1}$ & & & & \\
$\mathrm{O} 1-\mathrm{H} 1 \cdots \mathrm{N} 1$ & $0.85(1)$ & $1.86(4)$ & $2.608(7)$ & $147(7)$ \\
$\mathrm{N} 2-\mathrm{H} 2 \cdots \mathrm{O} 2^{\mathrm{i}}$ & $0.90(1)$ & $1.91(2)$ & $2.790(7)$ & $166(6)$ \\
$\mathrm{C} 7-\mathrm{H} 7 \cdots 2^{\mathrm{i}}$ & 0.93 & 2.51 & $3.198(5)$ & $131(6)$ \\
$\mathrm{C} 14-\mathrm{H} 14 \cdots \mathrm{O} 1^{\text {ii }}$ & 0.93 & 2.45 & $3.295(5)$ & $150(6)$ \\
$\mathbf{1}$ & & & & \\
$\mathrm{O} 3-\mathrm{H} 3 \cdots \mathrm{N} 2^{\text {iii }}$ & $0.85(1)$ & $1.92(3)$ & $2.739(7)$ & $162(10)$ \\
$\mathrm{C} 6-\mathrm{H} 6 \cdots \mathrm{O} 5^{\text {iv }}$ & 0.93 & 2.59 & $3.446(5)$ & $154(5)$ \\
$\mathbf{2}$ & & & & $176(3)$ \\
$\mathrm{O} 3-\mathrm{H} 3 \cdots \mathrm{N} 2^{\mathrm{v}}$ & $0.85(1)$ & $1.98(1)$ & $2.842(8)$ & $145(4)$ \\
$\mathrm{C} 13-\mathrm{H} 13 \cdots \mathrm{O} 5{ }^{\text {vi }}$ & 0.93 & 2.56 & $3.362(3)$ & \\
\hline
\end{tabular}

Symmetry codes: (i) $1 / 2+x, 1 / 2-y, 1 / 2+z$; (ii) $x, y, 1+z$; (iii) $1-x,-y, 1-z$; (iv) $1-x,-y, 2-z$; (v) $-x$, $1-y, 1-z$; (vi) $-x, 1-y, 2-z$. 


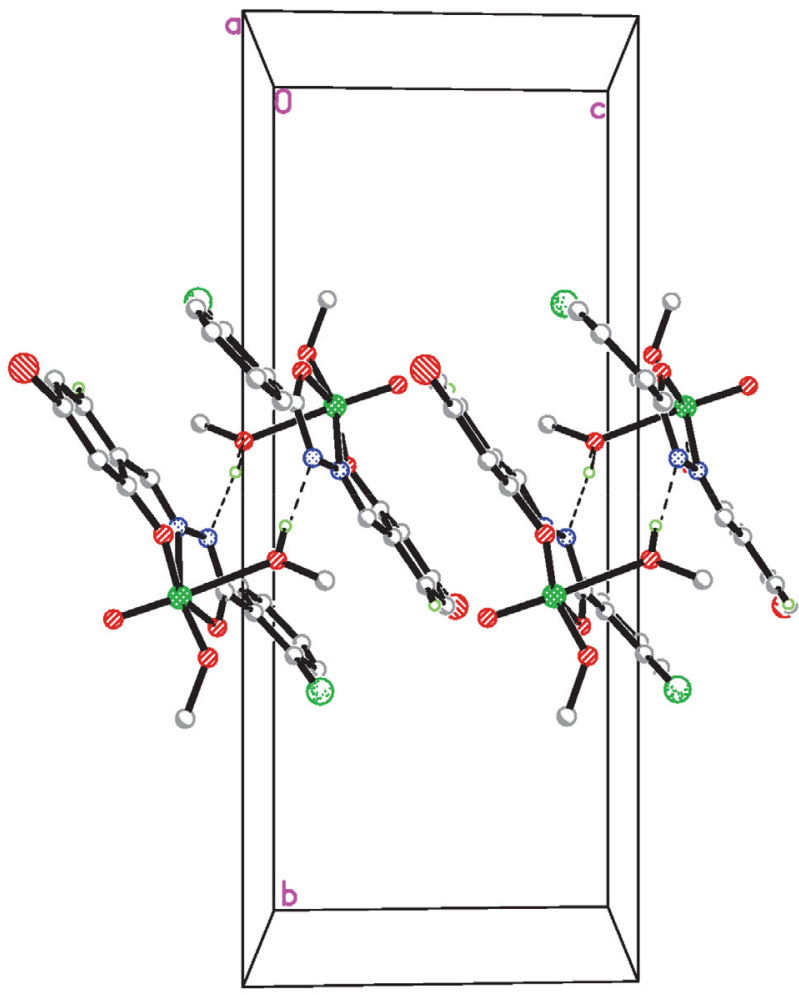

Figure 5. Molecular packing structure of complex 1, with hydrogen bonds shown as dotted lines.
As compared with the chloro-containing hydrazone 2-chloro- $N$ '-(3,5-dichloro-2-hydroxybenzylidene)benzohydrazide, ${ }^{7 \mathrm{c}} \mathrm{H}_{2} \mathrm{~L}^{1}$ is obviously weak for all the bacteria, while $\mathrm{H}_{2} \mathrm{~L}^{2}$ is similar except for $S$. aureus, a little weaker than the reported one. As for the vanadium complexes, complex $\mathbf{1}$ is similar to the reported vanadium complex with chloro-containing hydrazone ligand, while complex 2 is superior to the reported one against B. subtilis, E. coli and $P$. fluorescence. ${ }^{7 \mathrm{c}}$ Moreover, when compared with the vanadium complexes with chloro and fluoro-containing hydrazone ligands, both complexes are to some extent have higher MIC values. ${ }^{7 b, 15}$

When compared with the vanadium complexes with Schiff base ligand 2-((2-hydroxyethyl)imino)methyl)-6-methylphenol and the pyrone ligands 3-hydroxy2methyl-4H-pyran-4-one or 2-ethyl-3-hydroxy-4H-pyran4 -one, ${ }^{16}$ and the vanadium complexes with the ligands $N$ '-(5-chloro-2-hydroxybenzylidene)pivalohydrazide and 3-hydroxy2-methyl-4H-pyran-4-one or 2-ethyl-3-hydroxy-4H-pyran-4-one, ${ }^{17}$ the complexes $\mathbf{1}$ and $\mathbf{2}$ in this work is weaker for the bacteria $S$. aureus, E. coli, and $C$. albicans. ${ }^{16}$ The present complexes have higher activities against $B$. subtilis, $S$. aureus and $E$. coli, when compared with the vanadium complex with the ligands $N^{\prime}$-(3-bromo-2-hydroxybenzylidene)picolinohydrazide and 2-hydroxybenzohydroxamate. Interestingly, when the ligands changed to 2-chloro- $N^{\prime}$-(2-hydroxy-3-methoxybenzylide-

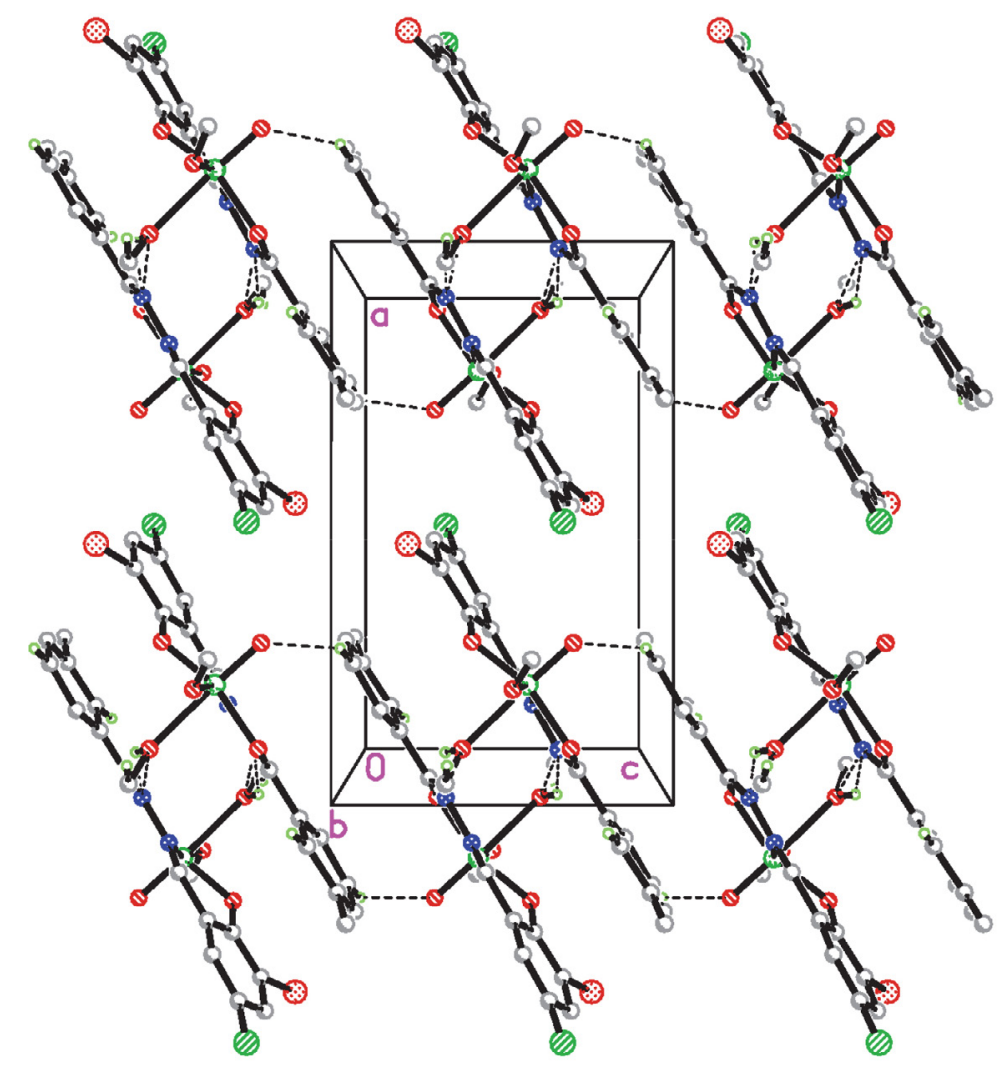

Figure 6. Molecular packing structure of complex 2, with hydrogen bonds shown as dotted lines. 
Table 4. Antimicrobial activities of the compounds with minimum inhibitory concentrations $\left(\mu \mathrm{gL}^{-1}\right)$

\begin{tabular}{lcccc}
\hline Tested material & B. subtilis & S. aureus & E. coli & P. fluorescence \\
\hline $\mathrm{H}_{2} \mathrm{~L}^{1}$ & 37.5 & 18.8 & 75 & $>150$ \\
$\mathrm{H}_{2} \mathrm{~L}^{2}$ & 9.4 & 9.4 & 37.5 & $>150$ \\
$\mathbf{1}$ & 4.7 & 9.4 & 17.5 & $>150$ \\
$\mathbf{2}$ & 2.3 & 4.7 & 9.4 & 37.5 \\
Penicillin G & 2.3 & 4.7 & $>150$ & $>150$ \\
\hline
\end{tabular}

ne)benzohydrazide and 2-hydroxybenzohydroxamate, the present complexes have higher activities against $B$. subtilis and E. coli, while lower activities against $S$. aureus. ${ }^{18}$

\section{6. TGA Analysis}

The thermograms of complexes $\mathbf{1}$ and $\mathbf{2}$ are shown as Figures 7 and 8, respectively. The decomposition mode of both complexes is similar. The neutral methanol ligands are removed between $80-120^{\circ} \mathrm{C}$, and the deprotonated

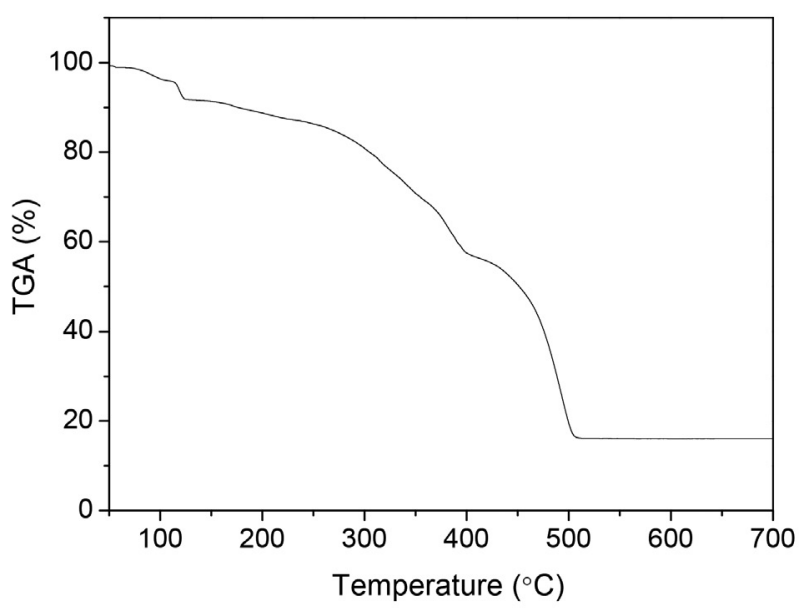

Figure 7. The TGA thermogram of complex 1 in air atmosphere.

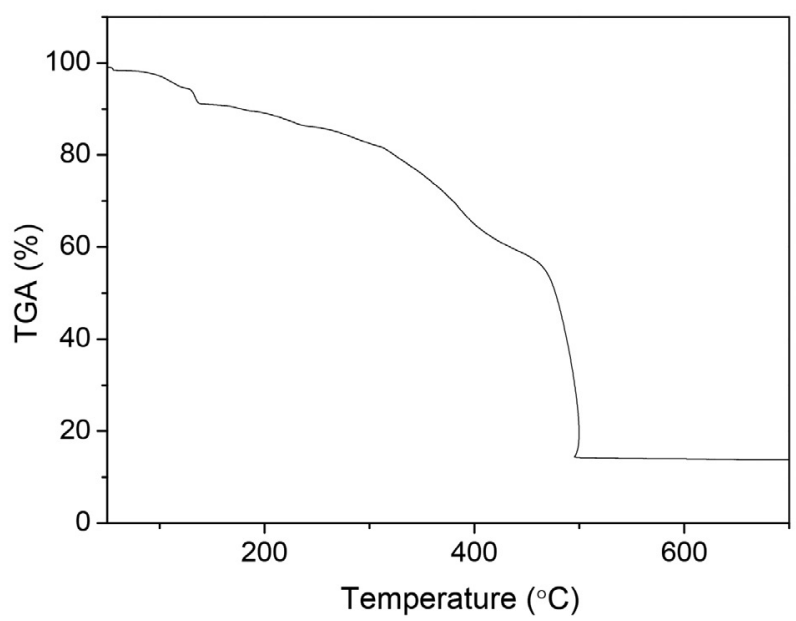

Figure 8. The TGA thermogram of complex 2 in air atmosphere. methanol ligands are removed between $115-120^{\circ} \mathrm{C}$ for complex 1 and $130-140^{\circ} \mathrm{C}$ for complex 2 . Then, the complexes continue to decompose between $150-510^{\circ} \mathrm{C}$. The residue remained about $510{ }^{\circ} \mathrm{C}$ is $17 \%$ for complex $\mathbf{1}$ and $16 \%$ for complex 2 , which is in accordance with the expected amount of $\mathrm{V}_{2} \mathrm{O}_{5}$.

\section{Supplementary Data}

CCDC $2012695\left(\mathrm{H}_{2} \mathrm{~L}^{1}\right), 1891034(\mathbf{1})$ and 2012696 (2) contain the supplementary crystallographic data for the compounds. These data can be obtained free of charge via http://www.ccdc.cam.ac.uk/conts/retrieving.html, or from the Cambridge Crystallographic Data Centre, 12 Union Road, Cambridge CB2 1EZ, UK; fax: (+44) 1223336-033; or e-mail: deposit@ccdc.cam.ac.uk.

\section{Acknowledgments}

This work was financially supported by K.C. Wong Magna Fund in Ningbo University, Ningbo Public Fund (Project No. 202002N3056) and the State Key Laboratory Development Fund of Structural Chemistry (Project No. 20190028).

\section{References}

1. (a) K. Pyta, A. Janas, M. Szukowska, P. Pecyna, M. Jaworska, M. Gajecka, F. Bartl, P. Przybylski, Eur. J. Med. Chem. 2019, 167, 96-104; DOI:10.1016/j.ejmech.2019.02.009

(b) R. Fekri, M. Salehi, A. Asadi, M. Kubicki, Inorg. Chim. Acta 2019, 484, 245-254; DOI:10.1016/j.ica.2018.09.022

(c) H. Y. Qian, Inorg. Nano-Met. Chem. 2018, 48, 461-466; DOI:10.1080/24701556.2019.1569689

(d) H. Y. Qian, Russ. J. Coord. Chem. 2017, 43, 780-786. DOI:10.1134/S1070328417110070

2. (a) D. A. Megger, K. Rosowski, C. Radunsky, J. Kosters, B. Sitek, J. Muller, Dalton Trans. 2017, 46, 4759-4767; DOI:10.1039/C6DT04613D

(b) N. R. Palepu, J. R. Premkumar, A. K. Verma, K. Bhattacharjee, S. R. Joshi, S. Forbes, Y. Mozharivskyj, K. M. Rao, Arabian J. Chem. 2018, 11, 714-728.

DOI:10.1016/j.arabjc.2015.10.011

3. (a) Y.-C. Liu, H.-L. Wang, S.-F. Tang, Z.-F. Chen, H. Liang, 
Anticancer Res. 2014, 34, 6034-6035;

(b) A. Erguc, M. D. Altintop, O. Atli, B. Sever, G. Iscan, G. Gormus, A. Ozdemir, Lett. Drug Des. Discov. 2018, 15, 193202. DOI:10.2174/1570180814666171003145227

4. (a) M. Zhang, D.-M. Xian, H.-H. Li, J.-C. Zhang, Z.-L. You, Aust. J. Chem. 2012, 65, 343-350; DOI:10.1071/CH11424

(b) L. Shi, H.-M. Ge, S.-H. Tan, H.-Q. Li, Y.-C. Song, H.-L. Zhu, R.-X. Tan, Eur. J. Med. Chem. 2007, 42, 558-564.

DOI:10.1016/j.ejmech.2006.11.010

5. N. P. Rai, V. K. Narayanaswamy, T. Govender, B. K. Manuprasad, S. Shashikanth, P. N. Arunachalam, Eur. J. Med. Chem. 2010, 45, 2677-2682. DOI:10.1016/j.ejmech.2010.02.021

6. (a) L.-H. Wang, X.-Y. Qiu, S.-J. Liu, J. Coord. Chem. 2019, DOI:10.1080/00958972.2019.1590561

(b) X. W. Zhu, Russ. J. Coord. Chem. 2018, 44, 335-339; DOI:10.3103/S1068367418040213

(c) Z. H. Chohan, S. H. Sumrra, M. H. Youssoufi, T. B. Hadda, Eur. J. Med. Chem. 2010, 45, 2739-2747;

DOI:10.1016/j.ejmech.2010.02.053

(d) O. Taheri, M. Behzad, A. Ghaffari, M. Kubicki, G. Dutkiewicz, A. Bezaatpour, H. Nazari, A. Khaleghian, A. Mohammadi, M. Salehi, Transition Met. Chem. 2014, 39, 253-259.

DOI:10.1007/s11243-014-9798-9

7. (a) C.-L. Zhang, X.-Y. Qiu, S.-J. Liu, Acta Chim. Slov. 2019, 66, 719-725; DOI:10.17344/acsi.2019.5241

(b) L.-Y. He, X.-Y. Qiu, J.-Y. Cheng, S.-J. Liu, S.-M. Wu, Polyhedron 2018, 156, 105-110; DOI:10.1016/j.poly.2018.09.017 (c) S. M. Wu, X. Y. Qiu, J. C. Wang, S. J. Liu, L. Y. He, Russ. J. Coord. Chem. 2019, 45, 384-390.

8. Bruker, SMART (Version 5.625) and SAINT (Version 6.01). Bruker AXS Inc., Madison, Wisconsin, USA, 2007.
9. G. M. Sheldrick, SADABS. Program for Empirical Absorption Correction of Area Detector, University of Göttingen, Germany, 1996.

10. G. M. Sheldrick, Acta Crystallogr. 2008, A64, 112-122. DOI:10.1107/S0108767307043930

11. J. Meletiadis, J. F. G. M. Meis, J. W. Mouton, J. P. Donnelly, P. E. Verweij, J. Clin. Microbiol. 2000, 38, 2949-2954. DOI:10.1128/JCM.38.8.2949-2954.2000

12. A. Sarkar, S. Pal, Polyhedron 2007, 26, 1205-1210. DOI:10.1016/j.poly.2006.10.012

13. (a) D.-L. Peng, Transit. Met. Chem. 2016, 41, 843-848; DOI:10.1007/s11243-016-0086-8

(b) X. W. Zhu, Russ. J. Coord. Chem. 2018, 44, 421-424. DOI:10.1134/S1070328418070084

14. (a) D. L. Peng, Russ. J. Coord. Chem. 2017, 43, 404-410; DOI:10.1134/S1070328417060045

(b) Y. Li, L. Xu, M. Duan, J. Wu, Y. Wang, K. Dong, M. Han, Z. You, Inorg. Chem. Commun. 2019, 105, 212-216; DOI:10.1016/j.inoche.2019.05.011

(c) S. Guo, N. Sun, Y. Ding, A. Li, Y. Jiang, W. Zhai, Z. Li, D. Qu, Z. You, Z. Anorg. Allg. Chem. 2018, 644, 1172-1176.

DOI:10.1002/zaac.201800060

15. E.-C. Liu, W. Li, X.-S. Cheng, Acta Chim. Slov. 2019, 66, 971977.

16. G.-X. He, L.-W. Xue, Q.-L. Peng, P.-P. Wang, H.-J. Zhang, Acta Chim. Slov. 2019, 66, 570-575.

DOI: $10.17344 /$ acsi.2018.4868

17. L.-W. Xue, Y.-J. Han, X.-Q. Luo, Acta Chim. Slov. 2019, 66, 622-628. DOI:10.17344/acsi.2019.5039

18. H.-Y. Qian, Acta Chim. Slov. 2019, 66, 995-1001. DOI:10.4149/neo_2019_190112N36

\section{Povzetek}

Sintetizirali smo dva vanadijeva(V) kompleksa z bromo in kloro-substituiranima hidrazonoma $N^{\prime}$-(4-bromo-2-hidroksibenziliden)-2-klorobenzohidrazidom $\left(\mathrm{H}_{2} \mathrm{~L}^{1}\right)$ in $\mathrm{N}^{\prime}$-(3-bromo-5-kloro-2-hidroksibenziliden)-3-metilbenzohidrazidom $\left(\mathrm{H}_{2} \mathrm{~L}^{2}\right) \mathrm{s}$ formulo [ $\left.\mathrm{VOL}^{1}\left(\mathrm{OCH}_{3}\right)\left(\mathrm{CH}_{3} \mathrm{OH}\right)\right](1)$ in $\left[\mathrm{VOL}^{2}\left(\mathrm{OCH}_{3}\right)\left(\mathrm{CH}_{3} \mathrm{OH}\right)\right]$ (2) ter ju okarakterizirali $\mathrm{z}$ IR, UV-Vis in ${ }^{1} \mathrm{H}$ NMR spektroskopijo. Strukturo $\mathrm{H}_{2} \mathrm{~L}^{1}$ in obeh kompleksov smo določili z monokristalno rentgensko difrakcijo. Oba vanadijeva kompleksa sta enojedrna, kovinski atom je oktaedrično koordiniran s hidrazonskim ligandom, metanolom in metanolatnim ligandom ter okso skupino. Hidrazona in vanadijeva kompleksa smo testirali za antimikrobno delovanje na Bacillus subtilis, Staphylococcus aureus, Escherichia coli, Pseudomonas fluorescence, Candida albicans in Aspergillus niger. Prisotnost bromo in kloro skupin na hidrazonskem ligandu lahko izboljša antimikrobne lastnosti.

Except when otherwise noted, articles in this journal are published under the terms and conditions of the Creative Commons Attribution 4.0 International License 